\title{
Capacities and Obstacles of Kuwait Medical Educational Sector in Transitioning Education System to Online Form: A Paradigm Shift
}

\author{
Shafi AlDousari ${ }^{1}$ \\ ${ }^{1}$ Doctorate in Business Administration (DBA), Hull University, UK \\ Correspondence: Shafi AlDousari, Doctorate in Business Administration (DBA), Hull University, UK; UK Open \\ University/ Arab Open University (AOU) Partnership, KSA. E-mail: aousep2007@gmail.com
}

Received: August 8, 2021

Accepted: October 22, 2021 Online Published: November 17, 2021

doi:10.5539/ijbm.v16n12p88

URL: https://doi.org/10.5539/ijbm.v16n12p88

\begin{abstract}
Background: During this coronavirus outbreak, online teaching and learning have become highly common in medical education. The majority of students and professors have transitioned to this comparatively modern online learning model. While faculty members found the transition to online education to be overwhelming, they persevered. Aim: study aims to investigate the Kuwait Medical educational sector's capacities and obstacles in transitioning the education system to the online form. Method: This study used a close-ended survey questionnaire constructed on Google Forms and distributed to the participants via e-mail. The study used an online Google form for formulating the questionnaire survey, which was later sent to the participants via e-mail. Results: The results showed that most of the faculty members (53\%) were satisfied with online learning. The most prominent difficulty emphasized by the faculty members $(35 \%)$ was network vulnerability $\mathrm{n}$ online teaching. The majority of the faculty members $(45 \%)$ agreed that transitioning to remote teaching is a big challenge and that there is inequality for different technology uses (56\%). Conclusion: Online learning has been increasingly relevant in medical education in recent months. It has its own set of benefits for improving students' knowledge and skills, and it may be used as an instructional tool in medical school.
\end{abstract}

Keywords: capacities, educational sector, Kuwait, medical education, obstacles, online forum

\section{Introduction}

The pandemic has caused many significant changes in the teaching and learning procedures at higher educational institutes, which influenced the interaction between teachers and students. As a consequence of COVID-19, the universities were compelled to use online forums to carry out their activities with the students (Sobaih et al., 2020). In this context, governments worldwide took precautionary measures to avoid the spreading of the virus and make sure that the educational procedures keep their continuity; therefore, the universities worldwide adopted the online form of teaching and learning (Ali, 2020). Generally, online-based learning was considered as an option, an alternative to physical learning. Due to the current situation, it became a mandatory element through which educational institutes can carry out their activities (Abou El-Seoud et al., 2014).

As the universities are shifting towards fully online and blended teaching methods, there is much to discuss the pedagogy (Kirkwood \& Price, 2014). This shift could result in a change in students' perception of this way of teaching, and it may differ from the ones found in studies conducted before the pandemic. Previous studies show that online learning is beneficial to students because it is more student-centred and flexible (Dhawan, 2020). Moreover, online teaching makes students more interactive as it provides asynchronous and synchronous tools such as; video-conferences, chats, e-mail and forums (Marinoni et al., 2020; Adnan \& Anwar, 2020).

Online learning procedures can enhance the learning process. Still, when using this platform, there may be some elements that could be considered as obstacles and hurdles in the student's process of learning or gaining knowledge, such as; decreased level of motivation in students, late feedback or assistance because teachers might not be available at the time of need and feelings of isolation because of class fellows not being physically present (Alsalhi, Eltahir \& Al-Qatawneh, 2019). The recent years have observed considerable growth in technological solutions that provide effective teaching and learning to diverse students.

Information and communication technology (ICT) is giving challenges to the traditional teaching model as it offers vast opportunities in a conventional setup within the higher education system. But still, the online 
approach to learning also has its challenges. Several higher education institutions worldwide have started implementing online learning within their systems. It cannot be ignored that online learning is the new educational pedagogy of the future. Experts have predicted that students attending pre-arranged physical classes on pre-arranged times will vanish shortly (Blustain et al., 1997).

The online form of learning has not been well-researched at many educational institutes before adopting it into their system. The perceptions upheld by the teaching faculty consist of one of the main factors that influence online learning effectiveness. Keeping this in mind, the study investigates the Kuwait Medical educational sector's capacities and obstacles in transitioning the education system to the online form. The study analyzes the understanding of medical university teaching faculty perceptions of the transition that has taken place from physical classrooms to online mode of teaching and learning. To achieve this aim, the study has designed the following research questions:

Q1. What was teachers level of satisfaction towards online teaching?

Q2. What challenges were faced by the faculty members while switching to remote teaching?

Q3. Will online teaching become the new norm?

\section{Literature Review}

According to UNICEF (2020), in 190 countries more than 1.5 billion students due to COVID-19 pandemic are not able to attend their school physically. The unplanned and huge transition from traditional learning to online learning procedures has changed how medical institutes deliver courses to their students. This century's medical students are now exposed to online modules, textbooks, video lectures, and computer-based examinations. This teaching mode gave rise to a flipped classroom model for learning, which has now been practised by several medical colleges around the world (Williams, 2016; Schwartzstein \& Roberts, 2017). Medical institutions' experiences differ, but this can help them embrace synchronized online models during this crucial time (Khalil et al., 2020).

Online learning is defined by Ally (2008), as "The use of internet to interact with instructor, other learners and content; to access learning materials; and to acquire support during learning process, in order to gain knowledge, to nurture from the learning experience and to develop personal meaning." Online learning is categorized as synchronous and asynchronous. Synchronous technology comprises live interaction between teachers and students (such as video conferences, audio conferencing, web chats etc.) whereas asynchronous include significant delay in time between the instruction and its receipt like; e-mail, prior video recording, discussion forums etc. (Finkelstein, 2006). The use of online learning mode at medical universities can be more effective and easier to access a significant amount of information, particularly in this time of uncertainty such as the pandemic (Khalil et al., 2020).

According to a study conducted by Khalil et al. (2020), COVID-19 has increased the focus on online learning in the education system. In a recent study found that in 2015, in higher education institutions 6 million student have participated in at least one online course, as compared to 1.6 million in 2002. It is expected that this paradigm shift will become a permanent trend in medical education in future design. The implementation of online teaching was not an easy job because of many obstacles such as lack of internet access and smartphones in remote areas, little or no experience or awareness among the faculty members to conduct online classes and flawed technical support system, lack of interest among the teachers and the students (Solangi, Al Shahrani \& Pandhiani, 2018). Northcote et.al (2015) revealed that faculty felt high self-efficacy in online course alignment (effectively aligning objectives to learning activities and assessments) and low self-efficacy in selecting technological resources.Several teachers and students have now adopted this new form of online teaching and learning; however, several teachers still experience problems in this transition from face-to-face instruction to online mode. Teachers were challenged with the need to become accustomed to online learning. There is no unified theory of e-learning, to date many. According to Pange \& Pange (2011) many scholars agree that existing theories of learning can be modified, combine and or directly applied to e-learning.

Johannes et.al (2020) from regression analyses finds that information and communication technologies (ICT) tools, mainly to digital teachers capability and teacher education opportunities to learn digital competence, are contributory to adujusting to online teaching during school closures in COVID-19. It is suggested by Johnson et al. (2020) that teachers should use various strategies for learning and teaching, student evaluation and engagement that are focused on learning ina virtual environment during a crisis A recent study by Bao (2020) highlights five high-impacted principles for online education.

- effective delivery on online instructional information 
- high-quality participation to improve the breadth and depth of student's learning

- high relevance between online instructional design and student learning

- adequate support provided by faculty and teaching assistants to students

- contingency plan to deal with unexpected incidents of online education platforms.

\subsection{Strategy of Online Education (Massive Open Online Courses)}

There are many emerging educational innovation strategies in field of online education for example, Massive Open Online Courses (MOOCs) first used in 2008, in the United States higher education community and then rapidly developing since 2012 (Deng et al., 2019; Lambert, 2020; Maya et al., 2020). "MOOC" is used as acronym for "Massive Open Online Courses." This term was used by Dave Cormier from the University of Prince Edward Island (Canada) in 2008, as result of a large online courses (i.e., CCK08, also known as Connectivism and Connective Knowledge) that was run by Stephen Downers and George Siemens (Al-Rahmi et al., 2019; Ebner et al., 2020). These courses were free online courses which do not need any formal entry or previous knowledge requirements. Enrolments of a learners are depended on the their interested and totally voluntary (Liyanagunawardena,2012).

The online learner was provided with variety of collaborative tools as threaded discussion, blog and meeting tools to interact with their co- learners and their online instructors. Since 2012, MOOC Providers such as Udacity, Coursera and edX started to appear on horizon of the higher education (Gaebel, 2013). The three most dominant players of MOOC providers are Udacity, Coursera and edX. The Udacity was established and launched in February 2012; it was for-profit Silicon Valley start-up led by David Stavens, Sebastian Thrun and Mike Sokolsky in North America (Gayoung et al., 2016). According Zhang (2021), Udacity had 11.5 million users in August 2020. Another for-profit Silicon Valley start-up in North America led by two computer science professors Daphne Koller and Andrew Ng was established in April 2012 named as Coursera. It was partners with at least 118 world-class university including Princeton, Stanford, Brown, Duke, Johns Hopkins, Columbia, etc. The third MOOC provider that developed rapidly is edX, it was a self-funded nonprofit consortium of universities built by Harvard University and Massachusetts Institute of Technology (MIT) in may 2012, and majorly run by professors from MIT.

\subsection{Type of MOOCs}

There are two type of MOOC, first type is "cMOOC" model that is known as "Connectivist MOOC" was grounded on philosophy of connectivism (Daniel, 2012; Rodriguez, 2012), and it connect people across a common field or topic of discourse as it was a part of open educational resource movement (Daniel, 2012; Rodriguez, 2012; Zhang, 2012). cMOOC focused on generation and creation of knowledge (Daniel, 2012; Siemens, 2012) and emphasized on connected and collaborative learning (Horn, 2013). The second type of MOOC is currently most prevalent type that is "XMOOC" also known as "extended MOOC", which was grounded on the theories of cognitivism and behaviorism (Conole, 2015). xMOOC stressed on knowledge duplication (Siemens, 2012; Daniel, 2012) and it appeared as more like a regular postsecondary course with emphasis on test, assignment, video lectures, quizzes and discussion (Conole, 2015) which heavily depended on computerized assignment, peer assessment and information transmission (Bates, 2012; Roscorla, 2012). MOOC provider Udacity, Coursera and edX majority of courses were characterized as xMOOC.

\subsection{Participants of MOOCs}

Participants of MOOCs had been characterized predominantly from development countries as young, well-educated and full-time working professionals looking to learn new skill set for their career's advancement (Luik, 2019). Educators widely used MOOCs as means of their professional development to learn more about the subjects that they are teaching (Netwon, 2015). Largest portions of professional taking are made by educators from developing countries. Students that are most committed and engaged on MOOCs tended to be elementary and secondary school teachers, graduate assistants, college professors (Velesianos \& Shepherdson, 2015).

\subsection{Instructor's Experience of MOOCs}

Majority of instructors of MOOCs were happy with their first experience they reported to like to connect with students through Discussion Forums to share, discuss and exchange courses related subjects (Blackmon, 2018). Whereas the widely most cited challenged was the significant amount of time required to prepare the course (e.g., preparing the video lectures and upload them to MOOC platforms) than instructors had expected (Blackmon, 2018). Along time management issues, most instructors on MOOC expressed their concerns other issues as well such as, the beign unfamiliar with new features and technology glitches (Blackmon, 2018); student's work 
assessment with large numbers of students (Wang et al., 2019).

The challenges depend basically on the teachers' experience with the online mode of conducting the classes. For example, there were many situations where the faculty members develop an interest in this online mode of teaching and, in a short time, got used to the techniques (Rasheed, Kamsin, \& Abdullah, 2020). On the other hand, few faculty members still found it challenging and difficult to start working with it and found loopholes in the online system of delivering education (Rapanta et al., 2020). Allen \& Seaman (2016) says that despite the ongoing growth in online higher education the doubts remain regarding the quality of courses online. Efforts of an institution to implement a online education program successfully could be jeopardize due to the lack of quality controls as stated by a report issued on indicating the importance of high standards of good practice by The American Federation of Teachers. (Feldman et al. 2000). High quality of courses more expected to maximizes user satisfaction and encourages better learning outcomes. Some researchers indicate that peer review and standards are helpful in promoting quality of online courses (McGahan et al., 2015). According to Cutri et al. (2020) medical schools all over the global were recently out of balance despite the matter how well- prepared they were due to current forced shift to virtual teaching. School have realized that they are unlikely to return to traditional ways anytime soon due to the in sight of no ending to COVID-19 crisis; and also, that virtual learning has moved to a main modality than substitute for both learners and teachers. A recent on medical schools shows that there is overall acceptable readiness for online teachings with a need for improvement in using learning management system and online teaching and course design (Hosny et al., 2021)

There is a crucial role of academic faculty and tutors in guiding and supporting the transition from physical education to virtual education, however it has been recognized that development and changes in medical education are putting extra pressure on faculty (O'Doherty et al., 2018). Shehata et al., 2020 in her study of medication education post COVID-19 stated that one of the focus group individuals said that "Younger faculty started to shift uninvited to online learning and it was as the older faculty were lagging behind." She also stated that continuous training of staff might help them to deal with this challenge and safeguard continuity of teaching. For instance, hundreds of staff were qualified due to the help of various distance learning programs in Health Professions Education as the Diploma of Health Profession Education (Talaat \& Salem, 2009).

According to Howlett et al. (2009), online learning can be described as the use of technology to support, deliver, and enhance learning and teaching simultaneously, which means involvement of communication between the teachers and the learners utilizing the online content. Keeping this understanding of the online mode of teaching, the study tried to explore the faculty members of Kuwait's medical university towards online teaching and learning in this crucial time.

\section{Methodology}

\subsection{Study Design}

This study used a close-ended survey questionnaire constructed on Google Forms and distributed to the participants via e-mail. The study used an online Google form for formulating the questionnaire survey, which was later sent to the participants via e-mail.

\subsection{Study Sample and Participants}

With a $95 \%$ confidence level and a 5\% margin of error, the study approached 119 participants (teaching faculty members of the medical university) to fill up the online survey questionnaire. Only 110 forms were received out which only 100 forms were filled. Therefore, the study considered a sample size of 100 participants.

\subsection{Study setting and Data Collection}

The study was conducted in a Medical University Kuwait. The data was collected through a survey questionnaire which consisted of 20 questions based on a 4-5 Likert Scale.

\subsection{Validity and Reliability of the Questionnaire}

The internal consistency or reliability of the questionnaire checked through Cronbach Alpha. All the items of the questionnaire had values above 0.70 which is acceptable. Moreover, the validity of the questionnaire was done by getting it checked from 3 medical university professors. After receiving, minor changes were recommended which were rectified and then were distributed to the study participants for data collection.

\subsection{Data Analysis}

The data collected from the survey questionnaire were analyzed using descriptive statistical analysis showing frequencies and percentages of the study participants' responses. 


\section{Results}

A total of 100 faculty members participated in this study based upon a US credit system of education. In the initial part of the questionnaire, general background information was obtained about the participants, such as gender and academic position (Table 1). Only 36 out of 100 participants (36\%) were female; while, 64\% were male. Considering the theoretical position, most participants (44\%) were assistant professors; while, 23\%, 18\%, $13 \%$, and $2 \%$ were associate professors, professors, lecturer, and demonstrator, respectively.

Table 1. Demographic Profile

\begin{tabular}{llll}
\hline Items & Measures & Frequency & Percentage \\
\hline \multirow{3}{*}{ Gender } & Male & 64 & $64 \%$ \\
& Female & 36 & $36 \%$ \\
& Demonstrator & 2 & $2 \%$ \\
\multirow{4}{*}{ Academic position } & Lecturer & 13 & $13 \%$ \\
& Assistant professor & 44 & $44 \%$ \\
& Associate professor & 23 & $23 \%$ \\
& Professor & 18 & $18 \%$ \\
\hline
\end{tabular}

The results in Table 2 explain the experience of online teaching among the medical faculty members in Kuwait. The level of satisfaction among the faculty members about online education was (53\%). None of the faculty members was dissatisfied with online teaching. Upon asking about the degree of satisfaction with ease of communication with students, most faculty members (59\%) stated that they are satisfied. Most of the faculty members (69\%) used other tools for online teaching apart from the blackboard (5\%), zoom (15\%), edmodo $(0 \%)$, and google classroom (10\%). Regarding time spent in online teaching, most of the faculty members $(32 \%)$ stated that almost the same time is consumed as compared to face-to-face learning, while $28 \%$ of them said that more time is spent in online teaching than face-to-face learning. The most prominent difficulty highlighted by the faculty members (35\%) in online education was network vulnerability. Moreover, positive skills attained by them during online teaching experience included communication skills $(53 \%)$, patience (32\%), subject expertise $(10 \%)$, and compassion and empathy (5\%). As narrated by the faculty members $(45 \% 0$ stated that the most significant advantage of teaching experience was convenience and flexibility. Upon asking about continuing online teaching after overcoming the pandemic, most faculty members (45\%) replied with maybe; while, $26 \%$ and $29 \%$ answered yes and no, respectively.

Table 2. Experience of online teaching among the participants

\begin{tabular}{|c|c|c|c|}
\hline Question & Measures & Frequency & Percentage \\
\hline \multirow{5}{*}{ Level of satisfaction with online teaching } & Very satisfied & 21 & $21 \%$ \\
\hline & Satisfied & 53 & $53 \%$ \\
\hline & Unsatisfied to some extent & 26 & $26 \%$ \\
\hline & Dissatisfied & 0 & $0 \%$ \\
\hline & Very satisfied & 15 & $15 \%$ \\
\hline \multirow{2}{*}{$\begin{array}{l}\text { Degree of satisfaction with ease of communication with } \\
\text { students }\end{array}$} & Satisfied & 59 & $59 \%$ \\
\hline & Unsatisfied to some extent & 26 & $26 \%$ \\
\hline \multirow{6}{*}{ Tools used for online teaching } & Dissatisfied & 0 & $0 \%$ \\
\hline & Blackboard & 5 & $5 \%$ \\
\hline & Zoom & 15 & $15 \%$ \\
\hline & Edmodo & 0 & $0 \%$ \\
\hline & Google classroom & 10 & $10 \%$ \\
\hline & Other & 69 & $69 \%$ \\
\hline \multirow{3}{*}{$\begin{array}{l}\text { Time spent in online teaching in comparison to face to face } \\
\text { learning }\end{array}$} & More & 40 & $40 \%$ \\
\hline & Less & 28 & $28 \%$ \\
\hline & Almost same & 32 & $32 \%$ \\
\hline \multirow{3}{*}{ Most prominent difficulty in online teaching } & Committing to work & 10 & $10 \%$ \\
\hline & Committing to staff & 7 & $7 \%$ \\
\hline & Find a place convenient to work & 19 & $19 \%$ \\
\hline
\end{tabular}




\begin{tabular}{|c|c|c|c|}
\hline \multirow{7}{*}{ Positive skills during the online teaching experience } & Network vulnerability & 35 & $35 \%$ \\
\hline & Lack of private computer & 2 & $2 \%$ \\
\hline & Technical breakdown & 27 & $27 \%$ \\
\hline & Communication skills & 53 & $53 \%$ \\
\hline & Compassion and empathy & 5 & $5 \%$ \\
\hline & Patience & 32 & $32 \%$ \\
\hline & Subject expertise & 10 & $10 \%$ \\
\hline \multirow{5}{*}{ Advantages of teaching experience } & Variety of program and courses & 23 & $23 \%$ \\
\hline & Lower total cost & 16 & $16 \%$ \\
\hline & $\begin{array}{l}\text { The more comfortable learning } \\
\text { environment }\end{array}$ & 16 & $16 \%$ \\
\hline & Convenience and flexibility & 45 & $45 \%$ \\
\hline & $\begin{array}{l}\text { More interaction and more remarkable } \\
\text { ability to concentrate }\end{array}$ & 0 & $0 \%$ \\
\hline \multirow{3}{*}{$\begin{array}{l}\text { Online teaching should continue in middle school after } \\
\text { overcoming the COVID- } 19 \text { pandemic. }\end{array}$} & Yes & 26 & $26 \%$ \\
\hline & No & 29 & $29 \%$ \\
\hline & Maybe & 45 & $45 \%$ \\
\hline
\end{tabular}

Table 3 reflects the challenges experienced by the faculty members in online teaching. Majority of the faculty members agreed that transitioning to remote education is a big challenge (45\%). Teaching in the classroom is different from teaching courses designed for reliable online delivery. Furthermore, $53 \%$ stated that they were provided adequate support as well as the students in academic work. About the online forum used by the concerned university, most of the faculty members (63\%) stated that it is user-friendly. Majority of the faculty members also agreed that they have quickly adapted to new teaching environments $(63 \%)$, and they are keen to teach online courses complementing face-to-face instruction (48\%). However, 56\% stated that inequality was observed in the use of technology that is the wealthier communities used more demanding technologies whereas the poorer ones, used a mediocre level technology. Moreover, 56\% also stated that synchronous video-conferencing is disadvantageous for students with poor internet. Lastly, it was noted by $63 \%$ of the faculty members that people will get used to alternating between face-to-face teaching online in case of pandemic persisting unevenly. Also, $45 \%$ of the participants strongly agreed that the pandemic affected the mental health especially stress and anxiety developed whereas only $20 \%$ neither agree or disagree. Almost $30 \%$ of the participants reported to develop technology phobia and $20 \%$ neither agree nor disagree.

Table 3. Challenges faced by faculty members in online teaching

\begin{tabular}{|c|c|c|c|}
\hline Questions & Measures & Frequency & Percentage \\
\hline \multirow{5}{*}{ Transitioning to remote teaching is a big challenge for a medical faculty member } & Strongly agree & 29 & $29 \%$ \\
\hline & Agree & 45 & $45 \%$ \\
\hline & $\begin{array}{l}\text { Neither agree nor } \\
\text { disagree }\end{array}$ & 16 & $16 \%$ \\
\hline & Disagree & 8 & $8 \%$ \\
\hline & Strongly disagree & 2 & $2 \%$ \\
\hline \multirow{5}{*}{$\begin{array}{l}\text { Teaching in the classroom is different from teaching courses designed for dedicated } \\
\text { online delivery }\end{array}$} & Strongly agree & 35 & $35 \%$ \\
\hline & Agree & 56 & $56 \%$ \\
\hline & $\begin{array}{l}\text { Neither agree nor } \\
\text { disagree }\end{array}$ & 7 & $7 \%$ \\
\hline & Disagree & 2 & $2 \%$ \\
\hline & Strongly disagree & 0 & $0 \%$ \\
\hline \multirow{5}{*}{ Well support provided to medical faculty and students in academic work } & Strongly agree & 22 & $22 \%$ \\
\hline & Agree & 53 & $53 \%$ \\
\hline & $\begin{array}{l}\text { Neither agree nor } \\
\text { disagree }\end{array}$ & 15 & $15 \%$ \\
\hline & Disagree & 10 & $10 \%$ \\
\hline & Strongly disagree & 0 & $0 \%$ \\
\hline \multirow{2}{*}{ Numerous resources help medical instructors, teaching assistants, and other staff } & Strongly agree & 18 & $18 \%$ \\
\hline & Agree & 63 & $63 \%$ \\
\hline
\end{tabular}




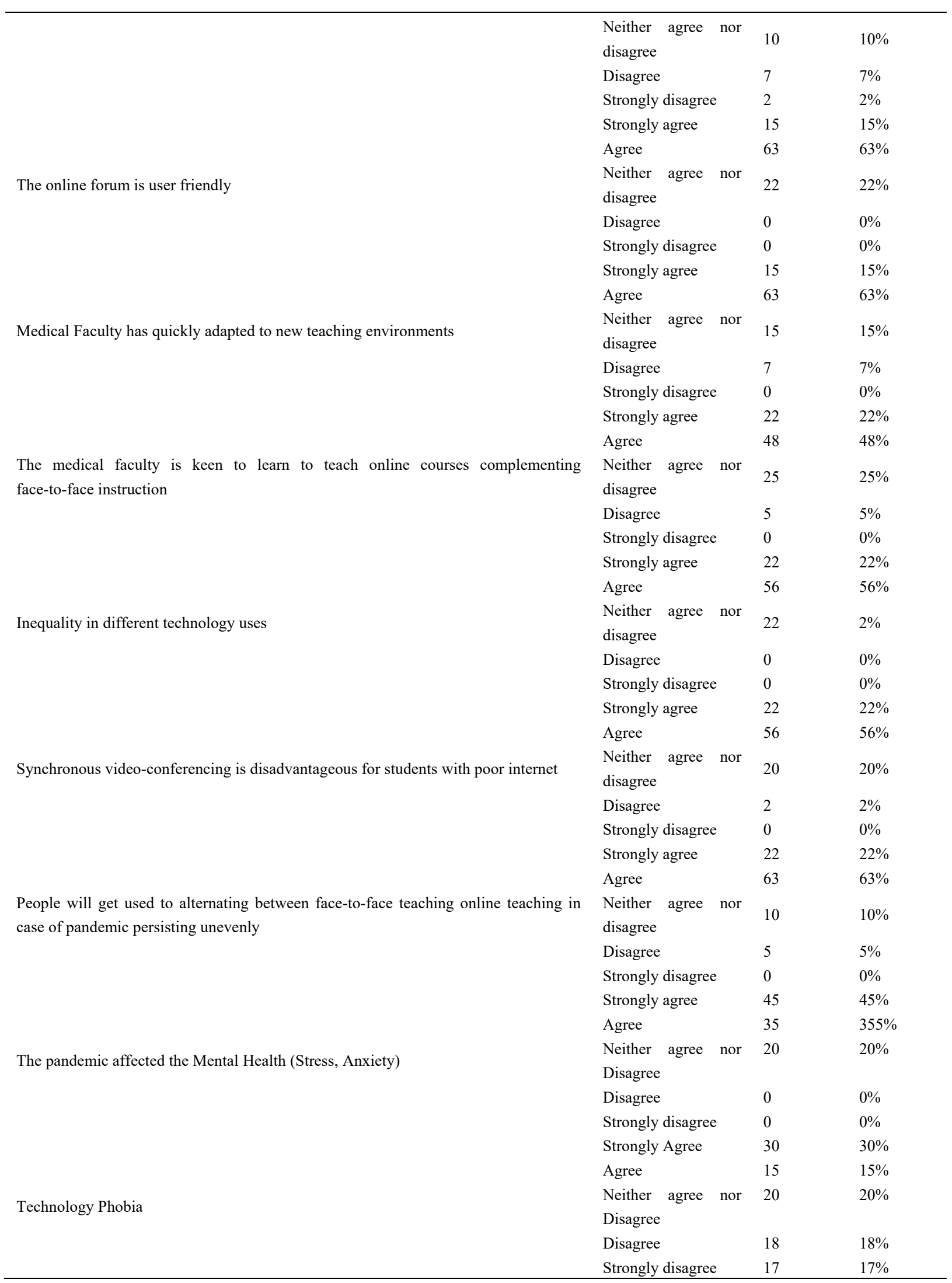

Table 3 shows the multivariate analysis, the online teaching platform used for distance learning $(\mathrm{OR}=66.4)$ showed improvement in the learning of the students $(\mathrm{OR}=22.7)$ and the medical faculty was provided adequate support by the university management $(\mathrm{OR}=7.1)$ and these were the most powerful factors compared to others. 
Table 4. Factors linked with satisfaction of teachers about online learning (Binary Logistic regression)

\begin{tabular}{|c|c|c|c|c|}
\hline \multirow[b]{2}{*}{ Factors } & \multirow[b]{2}{*}{ Odds ratio } & \multicolumn{2}{|l|}{ IC $95 \%$} & \multirow[b]{2}{*}{$P$-Value } \\
\hline & & Lower & Upper & \\
\hline $\begin{array}{l}\text { Online learning during the } \\
\text { pandemic }\end{array}$ & 66.4 & 1.8 & $2.3 * 10^{3}$ & 0.018 \\
\hline Improvement in performance & 22.7 & 4.2 & 123.8 & $<0.0001$ \\
\hline $\begin{array}{l}\text { Support provided by } \\
\text { university management }\end{array}$ & 7.1 & 1.4 & 39 & 0.024 \\
\hline $\begin{array}{l}\text { Distance learning courses } \\
\text { interactivity }\end{array}$ & 1.9 & 1.2 & 2.9 & 0.006 \\
\hline $\begin{array}{l}\begin{array}{l}\text { Constant in } \\
\text { (multivariate }\end{array} \\
\mathrm{B}=(-5.345)\end{array}$ & .005 & - & - & $<0.0001$ \\
\hline
\end{tabular}

\section{Discussion}

This study investigates the Kuwait educational sector's capacities and obstacles in transitioning the education system to the online form. An online questionnaire survey was distributed to the faculty members of the medical university in Kuwait. The first part of the survey form consisted of demographic details in which the majority of the participants were male. According to the findings of this study, the majority of the faculty members were very much satisfied and comfortable with the online teaching mode, and none of them was dissatisfied with it. This finding of the study is in line with another study conducted by Khalil et al. (2020) which states that online learning mode at medical universities can be more effective and easy to use, particularly at this time of uncertainty, such as the pandemic.

On the other hand, this finding is not in line with a study conducted by Rapanta et al. (2020) which states that the faculty members found it challenging and complex to use online teaching mode for delivering their lessons and end up finding loopholes in the online system of education. Moreover, the study also found that the time consumed in providing lessons was identical in both the modes: online and face-to-face classes. The faculty was also tech-savvy and used a variety of tools for conducting online courses, which helped them carry out their lessons more effectively. This finding is supported by a study conducted by Howlett et al. (2009), which stated that technological tools help support, deliver, and enhance teaching and learning simultaneously, which means that there is active interaction taking place between the teachers and students.

The majority of the faculty members showed their interest in continuing the online teaching mode even after overcoming COV-19. This finding is supported by a study conducted by Blustain et al. (1997), which found that students taking pre-arranged physical classes on pre-arranged times will disappear shortly. Another survey by Rasheed et al. (2020) also supported this finding of the study. According to them, the transition from face-to-face classes to online depends mainly upon the teacher's experience with the online mode of carrying out their lessons. For instance, there were many situations where the faculty members developed an interest in the online teaching method in a brief period. They got used to a different technological tool that facilitated them during their lessons. The study also found that the faculty members agreed that this transition from physical to online is a big challenge. This finding is aligned with the results of another study conducted by Alsalhi et al. (2019), which stated that though the online mode of teaching enhances the learning process, it also comes with some elements that can be considered hurdles obstacles that may make the process more challenging. The faculty members noticed inequality in terms of technological tools, such as they found that the wealthier communities use more advanced and demanding technology compared to the poor ones who used very ordinary specialized tools.

The study also noted that asynchronous teaching mode came with its own set of disadvantages. Students with a lousy internet connection could not make proper use of video or audio conferencing. The majority of the teaching faculty stated that people will now get help to alternating face-to-face teaching online in pandemic persisting unevenly. This result of the study is also supported by a survey conducted by Abou El-Seoud et al. (2014). They state that online-based learning was considered an option, an alternative to physical education. Due to the current scenario, it has now become mandatory through which educational institutes can carry out their activities. 


\section{Conclusion}

The faculty members in the present study thought that collaborative online learning was beneficial. Committing to work, committing to staff, find a place convenient to work, network vulnerability, lack of private computer, and technical breakdown were all difficulties for the faculty members. Furthermore, relative to faculty members, they were more likely to use online lectures as their preferred mode of instruction for the coming academic year.

The abrupt shift to online pedagogy education in developed countries due to COVID-19 has shown certain inequalities and obstacles whilst still providing some benefits. The present study results back up the evidence for online learning's usefulness for medical students; however, it is crucial to remember that it is not the only way to transfer skills effectively. There are, of course, other educational methods and clinical teaching that must be implemented as part of an optimal undergraduate medical education model. As a result, the online module's primarily coordinated learning offers a meaningful and exciting opportunity for the future of medical education. It can be incorporated into the curriculum to improve lifelong learning effectiveness. Future studies are needed to assess efficient online and offline instructional modalities and a meticulous paradigm incorporating an optimum proportion of online learning for undergraduate medical education.

\section{References}

Abou El-Seoud, M., Taj-Eddin, I., Seddiek, N., El-Khouly, M., \& Nosseir, A. (2014). E-learning and students' motivation: A research study on the effect of e-learning on higher education. International Journal of Emerging Technologies in Learning (iJET), 9(4), 20-26.

Adnan, M., \& Anwar, K. (2020). Online Learning amid the COVID-19 Pandemic: Students' Perspectives. Online Submission, 2(1), 45-51.

Ali, W. (2020). Online and remote learning in higher education institutes: A necessity in light of COVID-19 pandemic. Higher Education Studies, 10(3), 16-25.

Allen, I. E., \& Seaman, J. (2016). Online report card: Tracking online education in the United States. Wellesley: Babson Research Group.

Allen, I. E., \& Seaman, J. (2017). Digital learning compass: Distance education enrollment report 2017. Babson Survey Research Group, e-Literate, and WCET.

Ally, M. (2008). Foundations of educational theory for online learning. In T. Anderson (Ed.), The Theory and Practice of Online Learning. Athabasca University Press, Edmonton, AB.

Al-Rahmi, W., Aldraiweesh, A., Yahaya, N., Kamin, Y. B., \& Zeki, A. M. (2019). Massive open online courses (MOOCs): Data on higher education. Data in Brief, 22, 118-125.

Alsalhi, N. R., Eltahir, M. E., \& Al-Qatawneh, S. S. (2019). The effect of blended learning on the achievement of ninth-grade students in science and their attitudes towards its use. Heliyon, 5(9), e02424.

Bao, W. (2020). COVID-19 and online teaching in higher education: A case study of Peking University. Hum Behav \& Emerg Tech., 2, 113-115. https://doi.org/10.1002/hbe2.191

Bates, T. (2012). What's right and what's wrong about Coursera-style MOOCs. Retrieved from https://www.tonybates.ca/2012/08/05/whats-right-and-whats-wrong-about-coursera-stylemoocs/

Blackmon, S. (2018). MOOC makers: Professors' experiences with developing and delivering MOOCs. International Review of Research in Open and Distributed Learning, 19(4).

Conole, G. G. (2015). MOOCs as disruptive technologies: Strategies for enhancing the learner experience and quality of MOOCs. Revista de Educación a Distancia, (39).

Cutri, R. M., Mena, J., Whiting, E. F. (2020). Faculty readiness for online crisis teaching: transitioning to online teaching during the COVID-19 pandemic. Eur $J$ Teach Educ., 43(4), 523-541. https://doi.org/10.1080/02619768.2020.1815702

Daniel, J. (2012). Making sense of MOOCs: Musings in a maze of myth, paradox and possibility. Journal of Interactive Media in education, (3).

Deng, R., Benckendorff, P., \& Gannaway, D. (2019). Progress and new directions for teaching and learning in MOOCs. Computers \& Education, 129, 48-60.

Dhawan, S. (2020). Online learning: A panacea in the time of the COVID-19 crisis. Journal of Educational Technology Systems, 49(1), 5-22.

Ebner, M., Schön, S., \& Braun, C. (2020). More than a MOOC-seven learning and teaching scenarios to use 
MOOCs in higher education and beyond. In S. Yu, M. Ally, \& A. Tsinakos (Eds.), Emerging Technologies and Pedagogies in the Curriculum (pp. 75-87). Springer.

Feldman, S., McElroy, E. J., \& LaCour, N. (2000). Distance education, guidelines for good practice. Washington: American Federation of Teachers Retrieved http://www.umsl.edu/technology/frc/pdfs/guidlines_for_good_practice_DL.pdf

Finkelstein, J. E. (2006). Learning in real-time: Synchronous teaching and learning online (Vol. 5). John Wiley \& Sons.

Gaebel, M. (2014). MOOCs: Massive open online courses. European University Association. Retrieved from https://eua.eu/downloads/publications/moocs\%20-\%20massive\%20open\%20online\%20cou rses.pdf

Gayoung, L. E. E., Sunyoung, K. E. U. M., Myungsun, K. I. M., Yoomi, C. H. O. I., \& Ilju, R. H. A. (2016). A study on the development of a MOOC design model. Educational Technology International, 17(1), 1-37.

Horn, D. (2013). Failing fast, not spectacularly. Forbes. Retrieved from http://www.forbes.com/sites/michaelhorn/2013/08/15/fail-fast-not-spectacularly/

Hosny, S., Ghaly, M., Hmoud AlSheikh, M., Shehata, M. H., Salem, A. H., \& Atwa, H. (2021). Developing, Validating, and Implementing a Tool for Measuring the Readiness of Medical Teachers for Online Teaching Post-COVID-19: A Multicenter Study. Advances in Medical Education and Practice, 12, 755-768. https://doi.org/10.2147/AMEP.S317029

Howlett, D., Vincent, T., Gainsborough, N., Fairclough, J., Taylor, N., Cohen, J., \& Vincent, R. (2009). Integration of a case-based online module into an undergraduate curriculum: what is involved and is it effective? E-Learning and Digital Media, 6(4), 372-384.

Johannes, K., Daniela, J. J. B., \& Nina, G. (2020). Adapting to online teaching during COVID-19 school closure: teacher education and teacher competence effects among early career teachers in Germany. European Journal of Teacher Education, 43(4), 608-622. https://doi.org/10.1080/02619768.2020.1809650

Khalil, R., Mansour, A. E., Fadda, W. A., Almisnid, K., Aldamegh, M., Al-Nafeesah, A., ... \& Al-Wutayd, O. (2020). The sudden transition to synchronized online learning during the COVID-19 pandemic in Saudi Arabia: a qualitative study exploring medical students' perspectives. BMC medical education, 20(1), 1-10.

Kirkwood, A., \& Price, L. (2014). Technology-enhanced learning and teaching in higher education: what is enhanced and how do we know? A critical literature review. Learning, Media and Technology, 39(1), 6-36.

Lambert, S. R. (2020). Do MOOCs contribute to student equity and social inclusion? A systematic review 201418. Computers \& Education, 145, 103693.

Liyanagunawardena, T. R., Adams, A. A., \& Williams, S. A. (2013). MOOCs: A systematic study of the published literature 2008-2012. The International Review of Research in Open and Distributed Learning, 14(3), 202-227.

Luik, P., Feklistova, L., Lepp, M., Tõnisson, E., Suviste, R., Gaiduk, M., \& Palts, T. (2019). Participants and completers in programming MOOCs. Education and Information Technologies, 24(6), 3689-3706.

Marinoni, G., Van't Land, H., \& Jensen, T. (2020). The impact of Covid-19 on higher education around the world. IAU Global Survey Report.

McGahan, S. J., Jackson, C. M., \& Premer, K. (2015). Online course quality assurance: Development of a quality checklist. InSight: A Journal of Scholarly Teaching, 10, 126-140.

Newton, D. (2015). The (accidental) power of MOOCs. The Atlantic. Retrieved from https:/www.theatlantic.com/education/archive/2015/06/the-secret-power-ofmoocs/396608/

Northcote, M., Gosselin, K. P., Reynaud, D., Kilgour, P., Anderson, M. (2015). Navigating learning journeys of online teachers: threshold concepts and self-efficacy. Issues Educ Res., 25(3), 319-344.

O’Doherty, D., Dromey, M., Lougheed, J., Hannigan, A., Last, J., \& McGrath, D. (2018). Barriers and solutions to online learning in medical education-an integrative review. BMC medical education, 18(1), 1-11.

Pange A., \& Pange J. (2011) Is E-Learning Based on Learning Theories? A Literature Review. World Academy of Science, Engineering and Technology, 5(8), 56-60.

Rapanta, C., Botturi, L., Goodyear, P., Guàrdia, L., \& Koole, M. (2020). Online university teaching during and after the Covid-19 crisis: Refocusing teacher presence and learning activity. Postdigital Science and Education, 2(3), 923-945. 
Rasheed, R. A., Kamsin, A., \& Abdullah, N. A. (2020). Challenges in the online component of blended learning: A systematic review. Computers \& Education, 144, 103701.

Rodriguez, C. O. (2012). MOOCs and the AI-Stanford like courses: Two successful and distinct course formats for massive open online courses. European Journal of Open, Distance and E-Learning, 1-13.

Roscorla, T. (2012). Massively open online courses are 'here to stay.' Center for Digital Education. Retrieved from http://www.centerdigitaled.com/policy/MOOCs-Here-to-Stay.html

Saunders, M. N., \& Lewis, P. (2012). Doing research in business \& management: An essential guide to planning your project. Pearson.

Schwartzstein, R. M., \& Roberts, D. H. (2017). Saying goodbye to lectures in medical school—paradigm shift or passing fad. $N$ Engl J Med, 377(7), 605-607.

Shehata, M. H., Abouzeid, E., Wasfy, N. F., Abdelaziz, A., Wells, R. L., \& Ahmed, S. A. (2020). Medical education adaptations post COVID-19: An Egyptian reflection. Journal of Medical Education and Curricular Development, 7, 2382120520951819.

Siemens, G. (2012). Massive open online courses as new educative practice. Blog Elearnspace. Retrieved from http://www.elearnspace.org/blog/2012/02/29/massive-open-online-courses-as-neweducative-practice.

Sobaih, A. E. E., Hasanein, A. M., \& Abu Elnasr, A. E. (2020). Responses to COVID-19 in higher education: Social media usage for sustaining formal academic communication in developing countries. Sustainability, $12(16), 6520$.

Solangi, Z. A., Al Shahrani, F., \& Pandhiani, S. M. (2018). Factors affecting Successful Implementation of eLearning: Study of Colleges and Institutes Sector RCJ Saudi Arabia. International Journal of Emerging Technologies in Learning, 13(6).

UNICEF. (2020). Children at increased risk of harm online during global COVID-19 pandemic. Retrieved from https://www.unicef. org/press-releases/children-increased-risk-harm-onlineduring-global-covid-19-pandemic

Veletsianos, G., \& Shepherdson, P. (2015). Who studies MOOCs? Interdisciplinarity in MOOC research and its changes over time. International Review of Research in Open and Distributed Learning, 16(3), 1-17.

Wang, Y., Fang, H., Jin, Q., \& Ma, J. (2019). SSPA: An effective semi-supervised peer assessment method for large scale MOOCs. Interactive Learning Environments, 1-19.

Williams, D. E. (2016). The future of medical education: flipping the classroom and education technology.

Zhang, Y. (2013). Benefiting from MOOC [Paper presentation]. EdMedia: World Conference on Educational Media and Technology, Victoria, Canada.

Zhang, Y. (2021). Faculty Experiences in Massive Open Online Courses (MOOCs) (Doctoral dissertation, University of Hawai'i at Manoa).

\section{Appendix}

\section{Questionnaire}

1. Gender:

\begin{tabular}{|l|l|}
\hline Male & Female \\
\hline
\end{tabular}

2. What is your academic position?

\begin{tabular}{|l|l|l|l|l|}
\hline Demonstrator & Lecturer & Assistant professor & Associate professor & Professor \\
\hline
\end{tabular}

3. Generally, how satisfied are you with online teaching?

\begin{tabular}{|l|l|l|l|l|}
\hline Very satisfied & Satisfied & $\begin{array}{l}\text { Unsatisfied to some } \\
\text { extent }\end{array}$ & Dissatisfied \\
\hline
\end{tabular}

4. What is/are the program used as tools in this experience of teaching? 


\begin{tabular}{|l|l|l|l|l|}
\hline Blackboard & Zoom & Edmoto & Google classroom & Other \\
\hline
\end{tabular}

5. What is the degree of your satisfaction with the ease of communicating with teacher/student during the online teaching experience?

\begin{tabular}{|l|l|l|l|}
\hline Very satisfied & Satisfied & $\begin{array}{l}\text { Unsatisfied to some } \\
\text { extent }\end{array}$ & Dissatisfied \\
\hline
\end{tabular}

6. What is your assessment of time spent in performing online teaching in comparison to face-to-face teaching?

\begin{tabular}{|l|l|l|}
\hline More & Less & Almost same \\
\hline
\end{tabular}

7. What is/are the most prominent defects/difficulties of online teaching?

\begin{tabular}{|l|l|l|l|l|l|}
\hline $\begin{array}{l}\text { Difficulty } \\
\text { committing to } \\
\text { time work }\end{array}$ & $\begin{array}{l}\text { Difficulty } \\
\text { committing to } \\
\text { staff }\end{array}$ & $\begin{array}{l}\text { Difficulty to } \\
\text { find a place } \\
\text { convenient to } \\
\text { work }\end{array}$ & $\begin{array}{l}\text { Network } \\
\text { vulnerability to } \\
\text { the internet }\end{array}$ & $\begin{array}{l}\text { Lack of private } \\
\text { computer }\end{array}$ & $\begin{array}{l}\text { Technical } \\
\text { breakdowns in } \\
\text { programs used }\end{array}$ \\
\hline
\end{tabular}

8. What are the positive skills you acquired during your online teaching experience?

\begin{tabular}{|l|l|l|l|}
\hline Communication skills & Compassion and empathy & Patience & Subject expertise \\
\hline
\end{tabular}

9. What is/are the advantages of this teaching experience?

\begin{tabular}{|l|l|l|l|l|l|}
\hline $\begin{array}{l}\text { Variety of programs } \\
\text { and courses }\end{array}$ & Lower total cost & $\begin{array}{l}\text { The more } \\
\text { comfortable } \\
\text { learning } \\
\text { environment }\end{array}$ & $\begin{array}{l}\text { Convenience and } \\
\text { flexibility }\end{array}$ & $\begin{array}{l}\text { More interaction } \\
\text { and more } \\
\text { remarkable ability } \\
\text { to concentrate }\end{array}$ \\
\hline
\end{tabular}

10. Do you think online teaching should be part of medical school teaching even after overcoming the corona pandemic?

\begin{tabular}{|l|l|l|}
\hline Yes & No & Maybe \\
\hline
\end{tabular}

11. Transitioning to teaching remotely in a disrupted environment is a big challenge for any faculty member.

\begin{tabular}{|l|l|l|l|l|}
\hline Strongly agree & Agree & $\begin{array}{l}\text { Neither agree nor } \\
\text { disagree }\end{array}$ & Disagree & Strongly disagree \\
\hline
\end{tabular}

12. Teaching in the classroom is different from teaching courses that were designed for dedicated online delivery

\begin{tabular}{|l|l|l|l|l|}
\hline Strongly agree & Agree & $\begin{array}{l}\text { Neither agree nor } \\
\text { disagree }\end{array}$ & Disagree & Strongly disagree \\
\hline
\end{tabular}

13. It is ensured that the faculty and students are well-supported in their academic work even under disrupted operations

\begin{tabular}{|l|l|l|l|l|}
\hline Strongly agree & Agree & $\begin{array}{l}\text { Neither agree nor } \\
\text { disagree }\end{array}$ & Disagree & Strongly disagree \\
\hline
\end{tabular}

14. There are numerous resources to help instructors, teaching assistants, or any other staff

\begin{tabular}{|l|l|l|l|l|}
\hline Strongly agree & Agree & $\begin{array}{l}\text { Neither agree nor } \\
\text { disagree }\end{array}$ & Disagree & Strongly disagree \\
\hline
\end{tabular}


15. Online forum developed by the university is user friendly

\begin{tabular}{|l|l|l|l|l|}
\hline Strongly agree & Agree & $\begin{array}{l}\text { Neither agree nor } \\
\text { disagree }\end{array}$ & Disagree & Strongly disagree \\
\hline
\end{tabular}

16. Faculty has adapted to new teaching environments quickly and has taken a realistic look at what learning outcomes are achievable $\backslash$

\begin{tabular}{|l|l|l|l|l|}
\hline Strongly agree & Agree & $\begin{array}{l}\text { Neither agree nor } \\
\text { disagree }\end{array}$ & Disagree & Strongly disagree \\
\hline
\end{tabular}

17. Faculty is keen to learn about used to teach online courses that can complement face-to-face instruction

\begin{tabular}{|l|l|l|l|l|}
\hline Strongly agree & Agree & $\begin{array}{l}\text { Neither agree nor } \\
\text { disagree }\end{array}$ & Disagree & Strongly disagree \\
\hline
\end{tabular}

18. There is inequality for different technology uses, with wealthier communities using more demanding technologies and poorer ones turns to tools with lower instruction demands

\begin{tabular}{|l|l|l|l|l|}
\hline Strongly agree & Agree & $\begin{array}{l}\text { Neither agree nor } \\
\text { disagree }\end{array}$ & Disagree & Strongly disagree \\
\hline
\end{tabular}

19. Synchronous video-conferencing is disadvantageous for students whose internet infrastructure is poorer

\begin{tabular}{|l|l|l|l|l|}
\hline Strongly agree & Agree & $\begin{array}{l}\text { Neither agree nor } \\
\text { disagree }\end{array}$ & Disagree & Strongly disagree \\
\hline
\end{tabular}

20. People get used to alternating between face-to-face teaching and wholly online instruction, in case of pandemic persisting unevenly.

\begin{tabular}{|l|l|l|l|l|}
\hline Strongly agree & Agree & $\begin{array}{l}\text { Neither agree nor } \\
\text { disagree }\end{array}$ & Disagree & Strongly disagree \\
\hline
\end{tabular}

\section{Copyrights}

Copyright for this article is retained by the author(s), with first publication rights granted to the journal.

This is an open-access article distributed under the terms and conditions of the Creative Commons Attribution license (http://creativecommons.org/licenses/by/4.0/). 